\title{
The bicuspid aortic valve and related disorders
}

A válvula aórtica bicúspide e desordens relacionadas

\author{
Shi-Min Yuan', Hua Jing" \\ Department of Cardiothoracic Surgery, Jinling Hospital, School of Clinical Medicine, Nanjing, Nanjing University, Jiangsu Province, People's Republic of China
}

KEY WORDS:

Aorta, thoracic.

Aortic valve.

Coronary artery disease.

Heart defects, congenital.

Endocarditis.

\begin{abstract}
Bicuspid aortic valve (BAV) is the most common congenital cardiac malformation, affecting $1-2 \%$ of the population, with strong male predominance. Individuals may have a normally functioning BAV, and may be unaware of its presence and the potential risk of complications. However, they may easily develop aortic valve disorders: either stenotic or regurgitant, or both. Today, BAV is recognized as a syndrome incorporating aortic valve disorders and aortic wall abnormalities, including aortic dilation, dissection or rupture. Congenital or hereditary diseases such as ventricular septal defect, patent ductus arteriosus, coarctation of the aorta, Turner's syndrome, Marfan's syndrome etc., may frequently be associated with BAV. Infective endocarditis and occasionally thrombus formation may develop during the lives of BAV patients. Elevated cholesterol or C-reactive protein may be seen in laboratory findings of these patients. Beta-blockers and statins are the possibilities for medical treatment, and aortic valve repair/replacement and ascending aorta replacement are indicated for patients with a severely diseased aortic valve and aorta. Rigorous follow-up throughout life is mandatory after BAV has been diagnosed. The aim of the present article was to describe the implications of BAV and its associated disorders, and to discuss diagnostic and treatment strategies.
\end{abstract}

\section{RESUMO}

A válvula aórtica bicúspide (VAB) é a malformação cardíaca congênita, mais comum afetando 1-2\% da população, com forte predominância no sexo masculino. Indivíduos afetados podem exibir funcionamento normal da VAB, ignorando sua presença e o potencial risco de complicações associadas. Mas podem facilmente desenvolver disfunções de valva aórtica, com estenose, regurgitação, ou ambas. Hoje em dia, a VAB é reconhecida como uma síndrome incorporando alterações de valva aórtica e anormalidades da parede aórtica, inclusive dilação da aorta, dissecção ou ruptura. Doenças congênitas ou hereditárias, como defeito do septo ventricular, canal arterial patente, coartação de aorta, síndrome de Turner, síndrome de Marfan etc., podem estar frequentemente associadas com VAB. A endocardite infecciosa e ocasionalmente formação de trombo podem se desenvolver durante a vida nos pacientes com VAB. Elevação do colesterol ou proteína C-reativa pode ser observada nos resultados laboratoriais desses pacientes. Betabloqueador e estatinas são as opções de tratamento médico e reparação/substituição da valva aórtica e substituição da aorta ascendente são indicadas para pacientes com doença grave da valva aórtica e artéria aorta. Acompanhamento rigoroso por toda a vida é obrigatório quando do diagnóstico da VAB. 0 objetivo do presente artigo é descrever as implicações do VAB assim como suas desordens associadas e discutir as estratégias de diagnóstico e tratamento.

\section{INTRODUCTION}

Bicuspid aortic valve (BAV) is the most common congenital cardiac malformation, affecting 1-2\% of the population, with strong male predominance. ${ }^{1}$ It may occur in isolation, or in association with other congenital heart diseases. ${ }^{2}$ Individuals may have a normally functioning BAV, and may be unaware of its presence and the potential risk of impending complications. ${ }^{3}$ They may typically remain asymptomatic until the third or fourth decade of life, when the valve becomes dysfunctional. They then require close follow-up, and valve replacement may be warranted. ${ }^{4}$ BAV can be associated with abnormalities of the aortic wall such as coarctation of the aorta, aortic dissection, aortic aneurysm and Turner's syndrome. ${ }^{4}$ It is now accepted that BAV is associated with both valve disease and aortic disease, ${ }^{5}$ thereby leading to increased morbidity and mortality, including aortic valve disorders, aortic wall abnormalities, endocarditis and other cardiovascular malformations. ${ }^{6}$ BAV has been identified at a prevalence of 4.6 cas- es per 1000 live births. The prevalence of BAV according to sex has been found to be 7.1 cases per 1000 among male neonates, and 1.9 per 1000 among female neonates. All newborns with BAV are asymptomatic. Mild aortic regurgitation has only been found in one neonate with BAV. ${ }^{6}$

\section{ETIOLOGY}

It has been noted that BAV is inheritable. Families presenting familial congenital BAV have been described. ${ }^{7}$ A patient with aneurysm of the ascending aorta and calcific stenosis of a BAV, whose brother also had a stenotic BAV, has been reported. ${ }^{8}$

The pathogenesis of BAV is unknown. Experiments on Syrian hamsters have revealed that BAV does not occur consequent to improper development of the conotruncal ridges, conotruncal malseptation, valve cushion agenesis, or lesions acquired after normal valvulogenesis. Fusion of the right and left valve cushions at the beginning of

IMD, PhD. Postdoctoral researcher, Department of Cardiothoracic Surgery, Jinling Hospital, School of Clinical Medicine, Nanjing University, Nanjing 210002, Jiangsu Province, People's Republic of China.

"MD. Professor and head, Department of Cardiothoracic Surgery, Jinling Hospital, School of Clinical Medicine, Nanjing University, Nanjing 210002, Jiangsu Province, People's Republic of China. 
valvulogenesis appears to be a key factor in BAV formation. ${ }^{9} \mathrm{~A}$ recent study has demonstrated that BAVs with fused right and noncoronary leaflets and those with fused right and left leaflets are different etiological entities. BAVs with fused right and noncoronary leaflets result from a morphogenetic defect that occurs before cardiac outflow tract septation on the basis of an exacerbated nitric oxide-dependent epithelialto-mesenchymal transformation. On the other hand, BAVs with fused right and left leaflets result from anomalous septation of the proximal portion of the cardiac outflow tract, caused by dysfunctional neural crest cells. ${ }^{10}$ Deficient fibrillin-1 content in the vasculature of BAV patients may trigger matrix metalloproteinase production, thereby leading to matrix disruption and dilation. ${ }^{11}$

It has been noted that the fibrillin-1 content was remarkably reduced in the aorta of BAV patients, compared with that of patients with a tricuspid aortic valve. ${ }^{12-14}$

\section{CORONARY ARTERY DISORDERS}

The incidence of left dominance in BAVs has been found to be unusually high (24.4-56.8\%), compared with the incidence in tricuspid valves (9.5\%). ${ }^{15-18}$ Patients with BAVs have higher incidence of immediate bifurcation of the left main coronary artery, and higher incidence of left main coronary length less than $10 \mathrm{~mm}$. The mean length of the left main coronary artery is significantly shorter in BAV patients. These variations from the usual coronary artery anatomy may be part of the developmental abnormalities responsible for BAVs. ${ }^{19}$ Anomalous origins of the right ${ }^{20,21}$ and left ${ }^{22}$ coronary arteries, association with annuloaortic ectasia, and anomalous origins of the left circumflex coronary artery ${ }^{23}$ and single left coronary artery, ${ }^{24}$ have been noted in patients with BAVs. Spontaneous coronary artery dissection may occur in BAV patients. ${ }^{25}$

\section{AORTIC VALVE DISORDERS}

BAVs may progress and become calcified, thus leading to varying degrees of severity of aortic stenosis or aortic regurgitation, or both, which may eventually necessitate surgical intervention. ${ }^{26} \mathrm{BAV}$ is recognized as a frequent cause of aortic stenosis in adults. Aortic stenosis has been found in $72 \%$ of adults with BAV. The stenotic valves were obstructed by nodular, calcareous masses, but commissural fusion was present in only eight cases. Primary aortic regurgitation without infective endocarditis was uncommon, and $32 \%$ had an apparently normally functioning aortic valve. ${ }^{27}$ Among the 600 patients analyzed, 213 (36\%) had pure aortic stenosis, 265 (44\%) had pure aortic regurgitation and $122(20 \%)$ had combined stenosis and regurgitation. BAVs represented $18 \%$, as the third most important cause of aortic disorder following degenerative and rheumatic changes, followed by infective endocarditis (5\%). ${ }^{28}$ In 388 patients with severe aortic valve disease alone, BAVs were found in $45 \%$ of the patients with aortic stenosis and $24 \%$ of the patients with aortic regurgitation. In 110 patients with severe combined aortic and mitral valve disease, BAVs were found in only $12 \% .{ }^{29} \mathrm{~A}$ double-blind placebo-controlled study illustrated that the patients recruited into the ASTRONOMER study were younger, with less severe aor- tic stenosis. The population of BAV patients was large and accounted for $48.9 \%{ }^{30}$ From echocardiography, the patients with a stenotic BAV had significantly larger anatomical aortic valve areas than effective aortic valve areas. The discrepancy relating to jet eccentricity was much bigger than that of the patients with a stenotic tricuspid aortic valve, thus indicating greater severity of valve dysfunctional hemodynamics. In other words, the jet eccentricity correlated with BAV. ${ }^{31}$

\section{AORTIC WALL ABNORMALITIES}

BAV patients tend to develop vascular abnormalities of the aorta, such as dilation, coarctation and dissection. Aortic dilation in BAV patients is thought to be caused by intrinsic aortic disease that is characterized by cystic medial necrosis and disruption of the extracellular matrix due to fibrillin deficiency. ${ }^{32}$ There is controversy in the literature regarding whether aortic dilation, aneurysm and dissection are hemodynamic complications of BAV or are associated changes. BAV is associated with accelerated degeneration of the aortic media, thus indicating that BAV disease is a pathological process, not a developmental event. ${ }^{11}$

In the ascending aorta as well as the pulmonary trunk, the severity of cystic medial necrosis, elastic fragmentation and changes in the smooth muscle cell orientation have been found to be significantly more severe in patients with bicuspid valves than in those with tricuspid valves. ${ }^{33}$ Factors leading to aortic dissection four years after the Bentall operation have been considered to be an impact of congenital BAV or proximal anastomosis of venous grafts, or both. ${ }^{34}$

Half of young patients with normally functioning BAVs have echocardiographic evidence of aortic dilation. Aortic dilation is believed to be a precursor of aortic rupture and dissection. ${ }^{11}$ Aortic dilation was found to be present in $83.2 \%$ of a group of patients, and $83.7 \%$ of the cases were in the middle of the ascending tract. ${ }^{35}$ Aortic stenosis and hypertension were the most significant predictors of mid-ascending aneurysm. ${ }^{36}$ Ninety-four percent of aortic dilations associated with normally functioning BAVs showed the same anatomical configuration, with dilation of the mid-ascending tract but normal root diameters, compared with $95 \%$ of dilations associated with stenotic tricuspid aortic valves. ${ }^{37}$ The diameter of the ascending aorta in patients with BAV and dilation was significantly larger than in those with a tricuspid aortic valve and dilation. The distance between the aortic valve level and the point of maximum diameter of the ascending aorta in BAV patients without dilation was greater than in coronary patients. All patients with BAV and enlargement of the ascending aorta showed asymmetric dilation of the vessel. ${ }^{38}$

Studies have suggested that patients with BAV have an intrinsic defect in the aortic wall that results in aortic disease, regardless of aortic valve function. ${ }^{39} \mathrm{BAV}$ was associated with significantly less intimal change, and less fragmentation and loss of elastic tissue, compared with patients with a tricuspid aortic valve. ${ }^{40}$ Type I and III collagens were significantly decreased in dilated aortas of BAV patients, compared with controls, particularly at the convexity. Expression of messenger RNA (ribonucleic acid) for collagens was lower than normal only in the re- 
gurgitant subgroup. Fewer smooth muscle cells and greater severity of elastic fiber fragmentation were observed at the convexity than at the concavity. ${ }^{41}$

BAV, aortic coarctation and systemic hypertension are established risk factors for aortic dissection in the general population and they often occur in Turner's syndrome. ${ }^{42}$ Approximately $25-30 \%$ of women with Turner's syndrome have a cardiovascular malformation, and in Turner's syndrome there appears to be a confluence of established risk factors, leading to aortic dissection. ${ }^{43,44}$ Among 119 cases of fatal dissecting aneurysm of the aorta, 11 cases of congenital BAV (9\%) were observed. Among the latter, three had coarctation of the aorta and one had Turner's syndrome without coarctation. In each case, cystic medial necrosis of the aorta was present. Hypertension was either established or inferred from cardiac weight in $73 \%$ of the cases. The high incidence among subjects with dissecting aneurysm suggested a causative relationship between BAV and aortic dissecting aneurysm. ${ }^{45}$

Pathological examination of surgical specimens from the aortic wall of patients with aortic dissection associated with BAV showed cystic medial necrosis or mucoid degeneration. ${ }^{46}$ Patients with BAV had thinner elastic lamellae of the aortic media and greater distances between the elastic lamellae than did patients with a tricuspid aortic valve. ${ }^{47}$ Matrix metalloproteinases (endogenous enzymes that degrade matrix components) have been implicated in atherosclerotic aortic aneurysm formation and appear to be elevated in the aorta of patients with BAVs. ${ }^{11}$

The association between Marfan's syndrome and BAVs is uncommon. ${ }^{48}$ However, many previous studies have outlined similarities between Marfan's syndrome and BAV. Both are prone to disruption of the aortic wall. In BAV patients, the impairment of aortic elasticity may result from abnormal elastic fibers in the degenerated aortic medial layer. ${ }^{49}$

\section{CONGENITAL HEART DEFECTS}

Patent ductus arteriosus and ventricular septal defect are the most frequent congenital heart defects associated with BAV. ${ }^{50,51}$ There is significantly higher incidence of aortic arch obstruction (51.1\%). ${ }^{52} \mathrm{No}$ significant relationship between the occurrence of BAVs and left ventricular outflow tract obstructions or mitral valve malformations have been noted. Concurrence of BAVs and bicuspid pulmonary valves has been detected in one study, and some cases presented trisomy\#18. The frequency of BAV in specimens with complete transposition of great arteries has been found to be only $1 \% .{ }^{53}$ Hypoplastic left heart syndrome, complete atrioventricular canal defect, Ebstein's anomaly, partial or total anomalous pulmonary venous return, tetralogy of Fallot, double-outlet right ventricle, ${ }^{54}$ septal left ventricular diverticulum, ${ }^{55}$ Williams syndrome, ${ }^{56}$ Down syndrome ${ }^{57}$ and annuloaortic ectasia ${ }^{58}$ are occasionally associated with BAV. Shone's complex, which is defined by four cardiovascular defects including supravalvular mitral membrane, valvular mitral stenosis with a parachute mitral valve, subaortic stenosis and aortic coarctation, is a rare entity and forms another association in BAV cases. ${ }^{59}$

\section{INFECTIVE ENDOCARDITIS}

Most patients with BAV will develop some complications during their lives. The most common and severe of these is infective endocarditis. Bayer et al. ${ }^{60}$ reported that BAV endocarditis represented only two out of 59 cases in native heart valves. The usual prevalence of infective endocarditis of BAVs is $10 \%$ to $16 \%{ }^{61}$ Most patients are unaware of their condition until the onset of infective endocarditis. ${ }^{62}$

Patients with BAV endocarditis are young, and there is strong male predominance. Staphylococci and viridans streptococci account for nearly three-quarters of the cases affecting BAVs ${ }^{61}$ Infective endocarditis in BAV patients may occur with aortic regurgitation and heart failure at an early age. Many of these patients need surgical intervention, with poor results. Endocarditis vegetation, perforation and perivalvular abscess may occur. ${ }^{62}$

\section{THROMBUS FORMATION}

Thrombus formation in a native BAV is a rare complicaton. ${ }^{63}$ Pathological studies have indicated that post-inflammatory changes occur in the resected $\mathrm{BAV}$, which is prone to develop thrombosis on the valve surface or in the calcification area. ${ }^{64}$ Microthrombus formation and valve thickening with incompetence could result in embolization, and subsequent cerebrovascular events. ${ }^{65}$ Embolization from calcific BAVs may lead to stroke and myocardial infarction. Conservative management with anticoagulation, to treat associated post-stagnation thrombosis, or aortic valve replacement as the treatment, is debatable. ${ }^{66}$ Sudden death may occur as a result of obstruction of the left ventricular outflow tract by a congenital BAV. ${ }^{67}$

\section{LABORATORY WORKUP}

BAV patients often have high levels of cholesterol and C-reactive protein. High serum cholesterol levels have been associated with massive calcification in BAV patients. ${ }^{68}$ C-reactive protein levels have been found to be higher among patients with moderate-to-severe valvular calcification than among patients without or with minimal valvular calcification. $\mathrm{Pa}$ tients with aortic stenosis may have higher $\mathrm{C}$-reactive protein levels than the levels in patients with aortic regurgitation. The C-reactive protein levels in BAV patients have not been found to correlate with aortic diameter, but have shown an association with advanced calcific valve disease. ${ }^{69}$ The plasma levels of C-reactive protein have been found to be higher in patients with BAVs or degenerative stenotic tricuspid aortic valves than in normal controls and patients with pure aortic regurgitation. ${ }^{70}$ In the presence of aortic dilation or infective endocarditis, patients may have anemia with an elevated erythrocyte sedimentation rate. ${ }^{59}$

\section{DIAGNOSIS AND TREATMENT}

The tests that may show a bicuspid aortic valve include magnetic resonance imaging of the heart and echocardiograms, which are sensitive enough to identify the presence or absence of BAVs. 
Table 1. Results from literature search in the major medical databases

\begin{tabular}{|c|c|c|c|c|}
\hline Database & Search strategies & & & Results \\
\hline Cochrane & \multirow[t]{2}{*}{ Bicuspid aortic valve } & 5 found & 4 related & 4 randomized controlled trials \\
\hline PubMed & & 1401 found & 1160 related & $\begin{array}{c}12 \text { case control studies } \\
440 \text { case reports } \\
41 \text { prospective comparative studies } \\
73 \text { prospective cohort studies } \\
3 \text { randomized controlled trials } \\
47 \text { retrospective comparative studies } \\
289 \text { retrospective cohort studies } \\
119 \text { research studies } \\
83 \text { reviews } \\
53 \text { others }\end{array}$ \\
\hline
\end{tabular}

Currently, the treatment for BAV is primarily surgical. Different surgical options exist for BAV patients, depending on the age at presentation and the size and appearance of the aorta. ${ }^{26}$ Patients with BAV should undergo elective repair of the aortic root or replacement of the ascending aorta if the diameter of these structures exceeds $5.0 \mathrm{~cm} .{ }^{71}$ Valve-sparing techniques, sometimes with pericardial leaflet extensions, may be the first choice. ${ }^{72,73}$ Triangular resection of the prolapsing larger cusp including the middle raphe, with or without a complementary subcommissural annuloplasty, may lead to satisfactory surgical outcomes. ${ }^{74}$ Aortic valve replacement is indicated for severe aortic stenosis or aortic insufficiency/regurgitation in symptomatic patients, or in those with abnormal left ventricular function. Peak gradient $\geq 80$ $\mathrm{mmHg}$ and aortic valve area $\leq 0.75 \mathrm{~cm}^{2}$ have been found to be predictive of aortic valve replacement for BAV patients. ${ }^{75}$ In neonates, critically stenotic BAVs can be relieved successfully, with a dramatic decrease in left ventricular pressure, through dilation by means of retrograde aortic balloon valvuloplasty. ${ }^{76}$

Triangular resection of the enlarged leaflet has been found to result in optimal valve function, thus leading to normal ventricular dimensions and functions after long-term follow-up. ${ }^{77}$ Reconstruction of incompetent BAVs may significantly reduce left ventricular volume load. ${ }^{78}$ Patients with severe left ventricular outflow tract obstruction who underwent the Ross-Konno procedure had a survival of $98.5 \%$ after a median follow-up of 2.4 years. ${ }^{79}$ Schmidtke et al. ${ }^{80}$ recommended that the subcoronary Ross procedure with pulmonary autograft for BAV patients should be used because of the stable postoperative root dimensions seen after long-term follow-up.

Patients with bicuspid valves should uniformly be advised to adhere to antibiotic prophylactics. ${ }^{1}$ It has been suggested that beta-blocker medications can reduce the progression of ascending aortic aneurysms, although the benefit of beta-blockers for preventing aortic dilation in BAV disease is unclear. Nonetheless, hypertension should be carefully monitored and controlled. ${ }^{81}$ Statin medications are useful for prevent- ing calcium buildup on the aortic valve, and for reducing the risk of aortic stenosis. ${ }^{26}$

A literature search was made in Lilacs, PubMed, Embase and the Cochrane Library using the search term "bicuspid aortic valve". A manual search of abstracts of articles was made to identify those relating to the topic. The results are presented in Table $\mathbf{1}$.

\section{CONCLUSIONS}

BAV has been recognized as a syndrome incorporating aortic valve disorders and aortic wall abnormalities. Congenital or hereditary diseases such as ventricular septal defect, patent ductus arteriosus, coarctation of the aorta, Turner's syndrome, Marfan's syndrome etc. may frequently be associated with BAV. Infective endocarditis and occasionally thrombus formation may develop during the lives of BAV patients. BAV and its associated disorders and possible complications place patients at higher risk. Regular follow-up becomes mandatory after BAV has been diagnosed, in order to closely observe such patients with regard to progression of the disease itself and its complications, and in order to suggest treatments. Beta-blockers and statins are the possibilities for medical treatment, and aortic valve repair/replacement and ascending aorta replacement are indicated for patients with a severely diseased aortic valve and aorta.

\section{REFERENCES}

1. De Mozzi P, Longo UG, Galanti G, Maffulli N. Bicuspid aortic valve: a literature review and its impact on sport activity. Br Med Bull. 2008;85:63-85.

2. Tirrito SJ, Kerut EK. How not to miss a bicuspid aortic valve in the echocardiography laboratory. Echocardiography. 2005;22(1):53-5.

3. Lewin MB, Otto $\mathrm{CM}$. The bicuspid aortic valve: adverse outcomes from infancy to old age Circulation. 2005;111(7):832-4

4. Ward C. Clinical significance of the bicuspid aortic valve. Heart. 2000;83(1):81-5.

5. Méndez I, Prado B, Gallego P, et al. Reparación valvular en la insuficiencia aórtica por válvula bicúspide: una alternativa? [Valve repair for bicuspid aortic valve regurgitation: an option?] Rev Esp Cardiol. 2007;60(2):209-12. 
6. Tutar E, Ekici F, Atalay S, Nacar N. The prevalence of bicuspid aortic valve in newborns by echocardiographic screening. Am Heart J. 2005;150(3):513-5.

7. Clementi M, Notari L, Borghi A, Tenconi R. Familial congenital bicuspid aortic valve: a disorder of uncertain inheritance. Am J Med Genet. 1996;62(4):336-8.

8. Gale AN, McKusick VA, Hutchins GM, Gott VL. Familial congenital bicuspid aortic valve: secondary calcific aortic stenosis and aortic aneurysm. Chest. 1977;72(5):668-70.

9. Sans-Coma V, Fernández B, Durán AC, et al. Fusion of valve cushions as a key factor in the formation of congenital bicuspid aortic valves in Syrian hamsters. Anat Rec. 1996;244(4):490-8.

10. Fernández B, Durán $\mathrm{AC}$, Fernández-Gallego $\mathrm{T}$, et al. Bicuspid aortic valves with different spatial orientations of the leaflets are distinct etiological entities. J Am Coll Cardiol. 2009;54(24):2312-8.

11. Fedak PW, de Sa MP, Verma S, et al. Vascular matrix remodeling in patients with bicuspid aortic valve malformation: implications for aortic dilatation. J Thorac Cardiovasc Surg. 2003;126(3):797-806.

12. Sá MPL. Avaliação histológica e molecular dos grandes vasos de base em portadores de valva aórtica bicúspide [Histologic and molecular evaluation of the great vessels in patients with bicuspid aortic valve disease] [thesis]. Rio de Janeiro: Faculdade de Medicina da Universidade Federal do Rio de Janeiro; 2001.

13. Leme MP, David TE, Butany J, et al. Molecular evaluation of the great vessels of patients with bicuspid aortic valve disease. Rev Bras Cir Cardiovasc. 2003;18(2):148-56.

14. Sá MPL, Bastos ES, Murad H. Valva aórtica bicúspide: fundamentos teóricos e clínicos para substituição simultânea da aorta ascendente [Bicuspid aortic valve: theoretical and clinical aspects of concomitant ascending aorta replacement]. Rev Bras Cir Cardiovasc. 2009;24(2):218-24.

15. Hutchins GM, Nazarian IH, Bulkley BH. Association of left dominant coronary arterial system with congenital bicuspid aortic valve. Am J Cardiol. 1978;42(1):57-9.

16. Higgins $\mathrm{CB}$, Wexler $\mathrm{L}$. Reversal of dominance of the coronary arterial system in isolated aortic stenosis and bicuspid aortic valve. Circulation. 1975;52(2):292-6.

17. Lerer PK, Edwards WD. Coronary arterial anatomy in bicuspid aortic valve. Necropsy study of 100 hearts. Br Heart J. 1981;45(2):142-7.

18. Scholz DG, Lynch JA, Willerscheidt AB, Sharma RK, Edwards JE. Coronary arterial dominance associated with congenital bicuspid aortic valve. Arch Pathol Lab Med. 1980;104(8):417-8

19. Johnson $A D$, Detwiler $J H$, Higgins $C B$. Left coronary artery anatomy in patients with bicuspid aortic valves. Br Heart J. 1978;40(5):489-93.

20. Palomo AR, Schrager BR, Chahine RA. Anomalous origin of the right coronary artery from the ascending aorta high above the left posterior sinus of Valsalva of a bicuspid aortic valve. Am Heart J. 1985;109(4):902-4.

21. Schang SJ, Pepine CJ, Bemiller CR. Anomalous coronary artery origin and bicuspid aortic valve. Vasc Surg. 1975;9(2):67-72.

22. Doty DB. Anomalous origin of the left circumflex coronary artery associated with bicuspid aortic valve. J Thorac Cardiovasc Surg. 2001;122(4):842-3.

23. Takahashi M, Ikeda U, Shimada K, Takeda H. Rare association of congenital bicuspid aortic valve, annuloaortic ectasia, and anomalous origin of left circumflex coronary artery. Cardiology. 1994;84(1):61-4

24. Morimoto K, Taniguchi I, Miyasaka S, Marumoto A. Bicuspid aortic valve stenosis with single coronary artery. Ann Thorac Cardiovasc Surg. 2005;11(4):267-9.

25. Labombarda F, Legallois $D$, Sabatier R. Spontaneous coronary artery dissection and bicuspid aortic valve. Arch Cardiovasc Dis. 2009;102(12):857-8.

26. Borger MA, David TE. Management of the valve and ascending aorta in adults with bicuspid aortic valve disease. Semin Thorac Cardiovasc Surg. 2005;17(2):143-7.

27. Fenoglio JJ Jr, McAllister HA Jr, DeCastro CM, Davia JE, Cheitlin MD. Congenital bicuspid aortic valve after age 20. Am J Cardiol. 1977;39(2):164-9.

28. Matsumura T, Ohtaki E, Misu K, et al. Etiology of aortic valve disease and recent changes in Japan: a study of 600 valve replacement cases. Int J Cardiol. 2002;86(2-3):217-23.

29. Turina J, Turina M, Krayenbühl HP. [Significance of the bicuspid aortic valve in the incidence of aortic valve defects in adults]. Schweiz Med Wochenschr. 1986;116(44):1518-23.

30. Chan KL, Teo K, Tam J, Dumesnil JG; Astronomer Investigators. Rationale, design, and baseline characteristics of a randomized trial to assess the effect of cholesterol lowering on the progression of aortic stenosis: the Aortic Stenosis Progression Observation: Measuring Effects of Rosuvastatin (ASTRONOMER) trial. Am Heart J. 2007;153(6):925-31.

31. Donal E, Novaro GM, Deserrano D, et al. Planimetric assessment of anatomic valve area overestimates effective orifice area in bicuspid aortic stenosis. J Am Soc Echocardiogr. 2005;18(12):1392-8.

32. Aboulhosn J, Child JS. Left ventricular outflow obstruction: subaortic stenosis, bicuspid aortic valve, supravalvar aortic stenosis, and coarctation of the aorta. Circulation. 2006;114(22):2412-22.
33. de Sa M, Moshkovitz $Y$, Butany J, David TE. Histologic abnormalities of the ascending aorta and pulmonary trunk in patients with bicuspid aortic valve disease: clinical relevance to the ross procedure. J Thorac Cardiovasc Surg. 1999;118(4):588-94.

34. Morishita A, Shimakura T, Nonoyama M, Takasaki T, Yoda M. Ascending aorta dissection associated with bicuspid aortic valve. Considerations 4 years after combined coronary artery bypass grafting and mitral valve replacement. Jpn J Thorac Cardiovasc Surg. 2001;49(6):368-72.

35. Robicsek F, Thubrikar MJ, Cook JW, Fowler B. The congenital bicuspid aortic valve: how does it function? Why does it fail? Ann Thorac Surg. 2004;77(1):177-85.

36. Della Corte A, Bancone C, Quarto C, et al. Predictors of ascending aortic dilatation with bicuspid aortic valve: a wide spectrum of disease expression. Eur J Cardiothorac Surg. 2007;31(3):397-404; discussion 404-5.

37. Bauer M, Siniawski H, Pasic M, Schaumann B, Hetzer R. Different hemodynamic stress of the ascending aorta wall in patients with bicuspid and tricuspid aortic valve. J Card Surg. 2006;21(3):218-20.

38. Bauer M, Gliech V, Siniawski H, Hetzer R. Configuration of the ascending aorta in patients with bicuspid and tricuspid aortic valve disease undergoing aortic valve replacement with or without reduction aortoplasty. J Heart Valve Dis. 2006;15(5):594-600.

39. Hahn RT, Roman MJ, Mogtader AH, Devereux RB. Association of aortic dilation with regurgitant, stenotic and functionally normal bicuspid aortic valves. J Am Coll Cardiol. 1992;19(2):283-8.

40. Collins MJ, Dev V, Strauss BH, Fedak PW, Butany J. Variation in the histopathological features of patients with ascending aortic aneurysms: a study of 111 surgically excised cases. J Clin Pathol. 2008;61(4):519-23.

41. Cotrufo M, Della Corte A, De Santo LS, et al. Different patterns of extracellular matrix protein expression in the convexity and the concavity of the dilated aorta with bicuspid aortic valve: preliminary results. J Thorac Cardiovasc Surg. 2005;130(2):504-11.

42. Homme JL, Aubry MC, Edwards WD, et al. Surgical pathology of the ascending aorta: a clinicopathologic study of 513 cases. Am J Surg Pathol. 2006;30(9):1159-68.

43. Gøtzsche CO, Krag-OIsen B, Nielsen J, Sørensen KE, Kristensen BO. Prevalence of cardiovascular malformations and association with karyotypes in Turner's syndrome. Arch Dis Child. 1994;71(5):433-6.

44. Elsheikh M, Casadei B, Conway GS, Wass JA. Hypertension is a major risk factor for aortic root dilatation in women with Turner's syndrome. Clin Endocrinol (Oxf). 2001;54(1):69-73.

45. Edwards WD, Leaf DS, Edwards JE. Dissecting aortic aneurysm associated with congenital bicuspid aortic valve. Circulation. 1978;57(5):1022-5.

46. Ando M, Okita $\mathrm{Y}$, Matsukawa $\mathrm{R}$, Takamoto $\mathrm{S}$. Surgery for aortic dissection associated with congenital bicuspid aortic valve. Jpn J Thorac Cardiovasc Surg. 1998;46(11):1069-73.

47. Bauer M, Pasic M, Meyer R, et al. Morphometric analysis of aortic media in patients with bicuspid and tricuspid aortic valve. Ann Thorac Surg. 2002;74(1):58-62.

48. Yalçin F, Sabah I. Marfan syndrome with bicuspid aortic valve diagnosed by transesophageal echocardiography. Turkish Journal of Medical Sciences. 1999;29(5):583-5. Available from: http://journals.tubitak.gov.tr/medical/issues/sag-99-29-5/sag-29-5-15-97208.pdf.Accessed in 2010 (Aug 30).

49. Fedak PW, David TE, Borger M, Verma S, Butany J, Weisel RD. Bicuspid aortic valve disease: recent insights in pathophysiology and treatment. Expert Rev Cardiovasc Ther. 2005;3(2):295-308.

50. Deshpande J, Kinare SG.. The bicuspid aortic valve - an autopsy study. Indian J Patho Microbiol. 1991;34(2):112-8.

51. Suzuki T, Nagai R, Kurihara $H$, et al. Stenotic bicuspid aortic valve associated with a ventricular septal defect in an adult presenting with congestive heart failure: a rare observation. Eur Heart J. 1994;15(3):402-3.

52. Cripe L, Andelfinger G, Martin L, Shooner K, Benson DW. Bicuspid aortic valve is heritable. J Am Coll Cardiol. 2004;44(1):138-43.

53. Duran AC, Frescura C, Sans-Coma V, et al. Bicuspid aortic valves in hearts with other congenital heart disease. J Heart Valve Dis. 1995;4(6):581-90.

54. Fernandes SM, Sanders SP, Khairy P, et al. Morphology of bicuspid aortic valve in children and adolescents. J Am Coll Cardiol. 2004;44(8):1648-51.

55. Yildirir A, Batur MK, Kabakci G. Left ventricular septal aneurysm in association with bicuspid aortic valve--a case report. Angiology. 2001;52(1):73-6.

56. Lopez-Rangel E, Maurice M, McGillivray B, Friedman JM. Williams syndrome in adults. Am J Med Genet. 1992;44(6):720-9.

57. Weinhouse E, Riggs TW, Aughton DJ. Isolated bicuspid aortic valve in a newborn with Down syndrome. Clin Pediatr (Phila). 1995;34(2):116-7.

58. Oyonarte Gómez M, Moyano Gizzi C, Terra Flores E, Barrientos CC. Endocarditis infecciosa mortal en portadora de anuloectasia aortica asociada a estenosis aortica biscuspide predominante: caso anatómo clínico [Infectious endocarditis mortal in a patient with annulo aortic ectasia and bicuspid valve aortic predominant. Anatomoclinical case]. Rev Méd Chile. 1992;120(1):62-8. 
59. Popescu BA, Jurcut R, Serban M, Parascan L, Ginghina C. Shone's syndrome diagnosed with echocardiography and confirmed at pathology. Eur J Echocardiogr. 2008;9(6):865-7.

60. Bayer AS, Ward JI, Ginzton LE, Shapiro SM. Evaluation of new clinical criteria for the diagnosis of infective endocarditis. Am J Med. 1994;96(3):211-9.

61. Lamas CC, Eykyn SJ. Bicuspid aortic valve--A silent danger: analysis of 50 cases of infective endocarditis. Clin Infect Dis. 2000;30(2):336-41.

62. Koichiro $\mathrm{N}$, Shigeru T, Takafumi $\mathrm{H}$, et al. Infective endocarditis in bicuspid aortic valve. Acta Cardiologica Paediatrica Japonica. 2000;16(6):907-12. Available from: http://sciencelinks. jp/j-east/article/200112/000020011201A0232749.php. Accessed in 2010 (Aug 30).

63. Wan S, DeSmet JM, Vincent JL, LeClerc JL. Thrombus formation on a calcific and severely stenotic bicuspid aortic valve. Ann Thorac Surg. 1997;64(2):535-6.

64. Chuangsuwanich T, Warnnissorn M, Leksrisakul P, et al. Pathology and etiology of 110 consecutively removed aortic valves. J Med Assoc Thai. 2004;87(8):921-34.

65. Pleet AB, Massey EW, Vengrow ME. TIA, stroke, and the bicuspid aortic valve. Neurology. 1981;31(12):1540-2.

66. Mahajan N, Khetarpal V, Afonso L. Stroke secondary to calcific bicuspid aortic valve: Case report and literature review. J Cardiol. 2009;54(1):158-61.

67. Karayel F, Ozaslan A, Turan AA, et al. Sudden death in infancy due to bicuspid aortic valve. J Forensic Sci. 2006;51(5):1147-50.

68. Rabuş MB, Kayalar N, Sareyyüpoğlu B, et al. Hypercholesterolemia association with aortic stenosis of various etiologies. J Card Surg. 2009;24(2):146-50.

69. Yagubyan M, Sarkar G, Nishimura RA, Sundt TM. C-reactive protein as a marker of severe calcification among patients with bicuspid aortic valve disease. Journal of Surgical Research. 2004;121(2):281. Available from: http://linkinghub.elsevier.com/retrieve/pii/ S0022480404003233. Accessed in 2010 (Aug 30).

70. Gerber IL, Stewart RA, Hammett CJ, et al. Effect of aortic valve replacement on c-reactive protein in nonrheumatic aortic stenosis. Am J Cardiol. 2003;92(9):1129-32.

71. Isselbacher EM. Thoracic and abdominal aortic aneurysms. Circulation. 2005;111(6):816-28.

72. Odim J, Laks H, Allada V, et al. Results of aortic valve-sparing and restoration with autologous pericardial leaflet extensions in congenital heart disease. Ann Thorac Surg. 2005;80(2):647-53; discussion 653-4.

73. Doss M, Sirat S, Risteski P, Martens S, MoritzA. Pericardial patch augmentation for repair of incompetent bicuspid aortic valves at midterm. Eur J Cardiothorac Surg. 2008;33(5):881-4.

74. Zalaquett RS, Camplá CC, Scheu MG, et al. Ciruguía reparadora de la válvula aórtica bicúspide insuficiente [Valve repair surgery for incompetent bicuspid aortic valves]. Rev Méd Chile. 2005;133(3):279-86.

75. Ahmed S, Honos GN, Walling AD, et al. Clinical outcome and echocardiographic predictors of aortic valve replacement in patients with bicuspid aortic valve. J Am Soc Echocardiogr. 2007;20(8):998-1003.

76. Lin YC, Chen MR. Balloon valvuloplasty for critical aortic stenosis in a low birth weight baby with tracheoesophageal fistula. J Formos Med Assoc. 2005;104(7):522-4.

77. Kasimir MT, Simon P, Seebacher G, et al. Reconstructed bicuspid aortic valve after 10 years: clinical and echocardiographic follow-up. Heart Surg Forum. 2004;7(5):E485-9.

78. Schmidtke C, Poppe D, Dahmen G, Sievers HH. Echocardiographic and hemodynamic characteristics of reconstructed bicuspid aortic valves at rest and exercise. Z Kardiol. 2005;94(7):437-44.

79. Hraska V, Krajci M, Haun Ch, et al. Ross and Ross-Konno procedure in children and adolescents: mid-term results. Eur J Cardiothorac Surg. 2004;25(5):742-7.

80. Schmidtke C, Bechtel M, Hueppe M, Sievers HH. Time course of aortic valve function and root dimensions after subcoronary ross procedure for bicuspid versus tricuspid aortic valve disease. Circulation. 2001;104(12 Suppl 1):121-4.

81. Nistri S, Grande-Allen J, Noale M, et al. Aortic elasticity and size in bicuspid aortic valve syndrome. Eur Heart J. 2008;29(4):472-9.

Sources of funding: Not declared

Conflict of interest: Not declared

Date of first submission: July 22, 2009

Last received: February 4, 2010

Accepted: September 8, 2010

Address for correspondence:

Hua Jing

Department of Cardiothoracic Surgery, Jinling Hospital

School of Clinical Medicine, Nanjing University

Nanjing 210002, Jiangsu Province, People's Republic of China

Tel. 862584801332

Fax. 862584824051

E-mail: dr.jing@163.com 